\title{
A Scale Development Study to MeasureSmartphone Satisfactions of Adolescents
}

\author{
Eray Yılmaz, T.C. ZiraatBankasıBalıkesir Science High School, Turkey \\ Erkan Duran, BalıkesirOvaköy Secondary School, Turkey \\ Ahmet Küçüktekeli, Balıkesir University, Turkey
}

\begin{abstract}
Smartphones are the most popular technological devices which enable the users to do multiple things at once such as connecting Internet, gaming, messaging, e-mailing and taking photographs in one device. In recent years, there has been a substantial rise in the sales of smartphones and the average age of their owners and replacement cycle have decreased. In this context, it is important to determine the motives and reasons why people replace their smartphones by spending high budgets and smartphone satisfactions of the users when purchasing the new ones. The aim of this study which derived from the importance of customer satisfaction is to develop a scale determining the smartphone satisfaction of adolescents between the ages of 15 and 22. In scale developing process, an item pool consisted of 46 items was constituted as a result of the compositions written by the participants and literature review. Pre-test of the draft scale was conducted with 70 students after the review of 7 field experts. In the pilot phase of study,exploratory factor analysis (EFA) was carried out through the data obtained from 716 students in order to perform construct validity. The draft scale consisted of 42 items before EFA turned into single factor structure scale consisted of 22 items after the analysis to determine the smartphone satisfactions of adolescents. Cronbach's Alfa $(\alpha)$ internal consistency of 5-point Likert-type scale was .932 and explained total variance was $39.360 \%$. In order to confirm factor structure as a result of EFA, confirmatory factor analysis (CFA) was carried out with 316 participants. All the indicators revealed that the single factor structure smartphone satisfaction scale at ideal levels by means of modification indices was valid and reliable, and it could be used in order to identify the smartphone satisfactions of adolescents in further studies.
\end{abstract}

Keywords: Smartphone, Satisfaction, Scale Development, Adolescent 


\section{Introduction}

In the last half-century information technologies arethe most leading innovations among the technologies developing at an unprecedented pace. Thanks to these technologies human life has been easier and daily lives of people havesteadily changed. Accessing, sharing information and communication have become as easy as touching a device in our hands. Smartphones have been known as the latest point in the field of information technologies since the invention of the radio.

Smartphones provide people with an opportunity to accomplish several tasks, more than a telephone that a computer can performwith the integrations of various devices in it (Güvenç, 2013). Smartphones are undoubtedly the most popular technological devices of our age. Smartphones enable the usersto do multiple things at once such as connecting Internet, gaming, messaging, e-mailing, and taking photographs in one device. According to We Are Social (2015) smartphones account for an increasingly great proportion of mobile use (38\%) among more than 7 billion active mobile subscriptions in worldwide. About one billion active Facebook users access their accounts via smartphones (69\%).However, as the number of smartphone users increases, smartphone addiction has become an annoying problem, harming work efficiency and social relations. In order to determine the degree of smartphone addiction of the individuals "Smartphone Addiction Scale" was developed by Kwon et.al. (2013). The scale was adapted to the Turkish language by Demirci, Orhan, Demirdaş, Akpınar and Sert (2014). Demirci et.al. (2014) found that $13 \%$ of the students defined themselves as smartphone addicts.

According to Turkish Statistical Institute data [TÜIKK] (2014), the rate of mobile phone penetration including smartphones in household increased to $96 \%$ in 2014 while it was $54 \%$ in 2004. Furthermore, mobile phone use among children aged between 6 and 15 starts at 10 on the average (TÜIK, 2013). The studies conducted with university students revealed that most of the students own their first mobile phones between the ages of 12 and 16. According to Karaaslan and Budak (2012) this rate was $67 \%$ and it was $75 \%$ for Uzgören, Şengür and Yiğit (2013).

Regarding the studies on the replacement cycle of mobile phones, it could be said that replacement rate between 0 and 2 years was about 30 \% (Çakır\&Demir, 2014; Çirkin, 2013; 
Karaaslan and Budak, 2012; Uzgören et. al., 2013). Moreover, $50 \%$ of the students were indecisive when to replace their mobile phones (Çakır \& Demir, 2014; Uzgörenet. al., 2013). According to the research conducted by Bal (2013) with 1175 participants, of the respondents $34 \%$ had replaced their mobile phones for getting broken down, $30 \%$ for being out of date, $15 \%$ for not having functions such as camera, MP3 and $3 \mathrm{G}$ and $9 \%$ for having short battery life. The similar studies asserted that the users replace their mobile phones for getting broken down or destroyed, not having the latest innovations, and not meeting the needs (Çakmak \& Yalçın, 2013; Çirkin, 2013; Türkay, 2011).

As it could be concluded from the research results, the expectations of the users are of great importance for replacing their smartphones. Böbrek (2011) defined the term "expectation" as the predictions of the costumer about what to encounter during the presentation of the service. Moreover, past experiences, advertisements, users' comments and price are the factors determining the expectation.

According to research carried out by Bal (2013) guarantee and service quality of the mobile phone had an important influence over the purchase decision (91\%), secondly technical specifications $(88 \%)$ and thirdly the price $(86 \%)$. In a similar study Çakmak and Yalçın (2013) stated that the most important features of smartphones that the students considered about while choosing were being user friendly (92\%), performance (86\%), and design (78 $\%$ ). In a study carried out by Taner (2013) brand of the smartphone was the most important feature over the purchase decision, then the model and theInternet connectivity followed successively. Furthermore, Çakır and Demir (2014) asserted that product specifications, brand, price, social factors and advertisements were the factors which had influence over the smartphone purchase decision. According to the research results conducted with 15092 smartphone users in the USA by J. D. Power and Associates (2014), $24 \%$ of the participants responded as operating system, $43 \%$ had the same operating system either with the PC or the tablet and the smart phone and $32 \%$ responded as specifications of the product when asked which features were the basic reason for choosing a smartphone.

When the literature on smartphone was reviewed, it was found that smartphone users replaced their phones because of various expectations and several factors existed influencing the purchase decision. Moreover, it could be said that the age of starting to mobile phone use 
among children is quite low and users replace their mobile phones very often. The factors affecting the reasons why users frequently replace their devicescould be explored by determining the satisfactions of the users.Definition of customer satisfaction was given by Oliver (1997) as"ajudgment that a product or service feature or the product or service itself,provided (or is providing) a pleasurable level of consumption-related fulfillment"(as cited in Sandıkç1, 2007). Furthermore, new customers were mostly affected by the recommendations of old customers rather than marketing tools and advertisement activities, thus costumer lost resulted from dissatisfaction and not meeting the needs and demands of the customers (Sandıç̧ı, 2007).Customer satisfaction is an important conceptboth for the producers and the customers. This concept which is the subject of several studies has been used as a model in many countries for years.

Customer Satisfaction Index [CSI] model is a cause and effect model putting "customer satisfaction" in the center, organizing "factors affecting customer satisfaction" and "outcomes as a result of satisfaction". The purposes of the indices are to evaluate performance of the companies through the eyes of the customers and to create a comparison tool both for the companies and the customers (Türkyılmaz \& Özkan, 2005).Despite some variations in National Customer Satisfaction Indices [NCSI] models, for Grigoroudis and Siskos (2004) expectations, company image, quality and value perceptions are the basic factors affecting customer satisfactions(as cited in Türkyılmaz \& Özkan, 2005). The most distinct features of the models are; the use of questionnaires for data collection instrument, rating the items ranging from 1 to 10 ( 1 is the lowest, 10 is the highest score) and the use of telephone in the application process (Türkyılmaz \& Özkan, 2005).

The current study aimed to develop a measuring scale in order to determine the smartphone satisfactions of high school and university students between the ages of 15 and 22. Therefore, it could be available to determine the motives and reasons why people replace their smartphones by spending high budgetsand smartphone satisfactions of the users when purchasing the new ones.

\section{Method}

In this study,the scale development process was composed of three phases; writing of compositions by the participants for the item pool, pre-test application, exploratory and 
confirmatory factor analyses for the construct validity. In this process survey model was used in order to explore the views of participants. The studies aiming data collection in order to identify the features of a group depend on survey model (Büyüköztürk, Kılıç-Çakmak, Akgün, Karadeniz \& Demirel, 2008).

\section{Participants}

The study was conducted with a total of 1160 high school and university students between the ages of 15 and 22 in Balikesir, Turkey in 2014-2015 academic years. In the process of the scale development 58 students for the writing of the compositions, 70 students for an exploratory factor analysis (EFA) and 716 students for confirmatory factor analysis (CFA).

\section{Development of the Smartphone Satisfaction Scale (SSS)}

To what extent the psychological features of an individual exist in accordance with his/her reactions are tried to be determined through the scales existed in the literature, whereas the aim of scale development is structuring of items to determine what the related psychological feature is (Erkuş, 2014). Therefore, the existing scale instruments were searched in related literature and then an item pool was constituted in order to develop the "Smartphone Satisfaction Scale" [SSS] which measures the satisfactions of adult smartphone users in high schools and universities.

\section{Constitution of the Item Pool}

In order to constitute the items of the scale,27 high school and 31 university students, a total of 58 students were requested to write a composition on the satisfactions of their smartphones. Content analysis was implemented to the collected text. 103 statements which are directly related or thought to be related were obtained. After the reorganization of the similar statements 34 items were obtained and 6 items were included as a result of the literature review. Moreover, 6 items more were added by the researchers and finally an item pool consisted of 46 items was constituted.

\section{Opinions of Experts for Content and Face Validity}

To ensure content validity, obtained items were asked the views of three academics, two teachers who are experts in the field of information technologies and two salespersons responsible from smartphones in a technology market. Depending on the opinions of the 7 
experts 19 items were reorganized, 3 items were excluded and a new proposal item was added. All the items in the draft scale were examined by two Turkish Language teachers in order to ensure lucidity and accuracy in the Turkish Language.

44 items were listed randomly in the draft scale which was conducted for pre-test application. The instruction defining the purpose of the study and the expectations from the participants was prepared. Satisfaction statements were administered with 5-pointLikert-type response categories ranging from strongly agree to strongly disagree.

The draft scale which was ready to use for pre-test applicationwas evaluated by two academics whowere holding Ph.D. degrees. Concerning the reviews of the experts all the items were investigated from the points of expression, content validity and whether the study was goal oriented.

\section{Conducting Pre-test Application}

The numbers of the participants must not be less than 50 for pre-test application in the research for scale development (Karasar, 1995). Therefore, in the current study the pre-test application was conducted with 70 participants, of the participants 38 of them were high school students and 32 of them were university students. The average amount of time the respondents spent for the scale was 10 minutes. After the pre-test application 8 items were reorganized and 2 items were excluded. The final scale was composed of 42 items to be conducted on the sample in order to ensure construct validity.

\section{Data Collection}

Four different types of high schools and a vocational school were identified with regard to maximum variation sampling method in order to apply the data collection instrument. The necessary permissions were gotten from Balıkesir Directorate of National Education by the researchers. The analysis were carried out with 716 data collection instruments for EFA of the draft scale consisted of 42 items and with 316 data collection instruments for CFA of final scale consisted of 22 items after EFA.

\section{Data Analysis}

In order to explore the construct validity of the scale, EFA was carried out using SPSS version 18.0. For Tavşancıl (2006) factor analysis which is one of the multivariate statistical 
analysis techniques reveals the order between each item in the scale and the response of the participants, and is used to identify the content of psychological dimensions. In order to confirm factor structure as a result of EFA, CFA was carried out using LISREL 8.7 software. Çokluk, Şekercioğlu and Büyüköztürk (2012) stated that it is the examination of the accuracy of the structure as a model which had been identified and limited previously using CFA.

\section{Findings}

The draft scale for CFA was conducted with 565 students from four high schools and 151 students from a vocational school as a total of 716 students. For Comrey and Lee (1992) in such an analysis, for adequate sample sizes 100 is poor, 200 is fair, 300 is good, 500 is very good and 1000 is excellent. Thus, the numbers of the participants in the current study is said to be almost excellent (as cited inAkbulut, 2010). In order to examine the size of the sample $\mathrm{KMO}$ and Barlett statistics were calculated $\left(\mathrm{KMO}=.957, X^{2}=880.862, \mathrm{p}<.001\right)$. KMO value was higher than .600 and the result of Barlett's test of sphericity was significant. Thus, it could be said that the sample was suitable for performing factor analysis (Cohen, Manion \& Morrison, 2007).

As the total correlations of 12 items in the draft scale consisted of 42 items were lower than .40 , they were taken out from the draft scale before the factor analysis. It was observed that the values of the rest of the items varied between .49 and .72 . According to Büyüköztürk (2009), the items having values above 40 are very good discriminators. Besides, EFA was carried out excluding two more items which raised the Cronbach's Alfa $(\alpha)$ value when they were taken out from the scale.

Maximum Likelihood method was preferred for EFA. For Stevens (1996) the aforementioned method considers the convenient common variance under the factors and has a stronger structure even in lower variance. In the unrotated analysis with 28 items, it was observed that five factors having eigenvalues higher than 5 and $44.867 \%$ of the total variance were explained. However, the eigenvalue in the first factor was 12 times of the eigenvalue in the second factor. Moreover, when the scree plot in Figure-1 was examined, a rapid fall was observed after the eigenvalue of the first factor and the contribution to the total variances of the other factors decreased. Therefore, as Çokluk et.al. stated (2012) number of factor can be determined as 1 . 


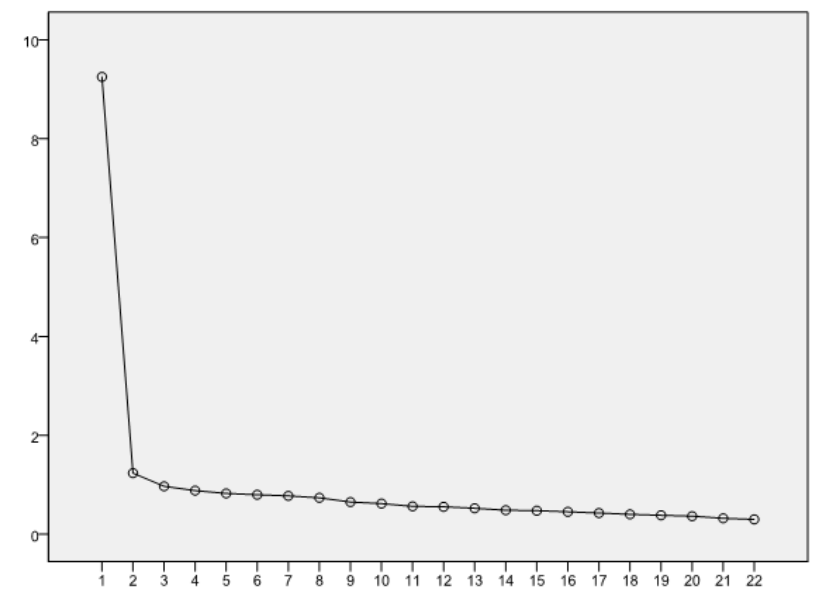

Figure 1. Scree Plot Graphic

It was found that in the analyses with regard to a single factor, communalities of five items were lower than .30 and total variance increased when excluded. For Büyüköztürk (2009) it is a good measure of choice for the factor load values of .45 and higher. In the current study cut-off pointwas determined as .50 and an item was excluded which was lower than this value. The factor loads of the scale with regard to its single factor structure ranged from .512 to .755 . Values were shown in Table 1.

Table 1.Factor Loads of the Items

\begin{tabular}{cccccc}
\hline Item & Factor Load & Item & Factor Load & Item & Factor Load \\
\hline M17 & .755 & M34 & .646 & M41 & .581 \\
M11 & .729 & M42 & .644 & M27 & .570 \\
M16 & .727 & M15 & .636 & M2 & .533 \\
M25 & .699 & M33 & .621 & M9 & .527 \\
M31 & .686 & M26 & .603 & M12 & .514 \\
M21 & .664 & M13 & .587 & M38 & .512 \\
M8 & .664 & M1 & .586 & & \\
M35 & .649 & M4 & .584 & & \\
\hline
\end{tabular}

Proportion of explained total variance in SSS which consisted of 22 items with a single factor was found as $39.360 \%$. According to Büyüköztürk (2009) for single factor analysis an explained total variance rate $30 \%$ and above is considered to be sufficient. Therefore, it 
could be said that the explained total variance in the single factor structure was sufficient. In the current study Cronbach's Alfa $(\alpha)$ internal consistency of the scale was .932. This value was above the high reliability limit which was recommended by Kalayc1 (2009) as .80. Thus, the results of measurements were said to be highly reliable.

The scale after EFA was administered to 316 participants. The accuracy of factor structure was tested by CFA on the obtained data. SPSS 18.0 and LISREL 8.7 software were used in the analysis. The fit of the model obtained as a result of CFA was tested by $\chi^{2}$, Root Mean Square Error of Approximation [RMSEA], Comparative Fit Index [CFI] and Goodness of Fit Index [GFI] (Brown, 2006; Tabachnick \& Fidell, 2001). The results of the analysis were given in Table 2.

Table 2.The Assessment of Confirmatory Factor Analysis

\begin{tabular}{ccc}
\hline Fit Index & Value & Assessment \\
\hline$\chi^{2}$ & 595.34 & - \\
\hline $\mathrm{df}$ & 207 & - \\
\hline $\mathrm{p}$ & .000 & - \\
\hline$\chi^{2} / \mathrm{df}$ & 2.88 & Perfect fit \\
\hline RMSEA & .077 & Good fit \\
\hline SRMR & .043 & Perfect fit \\
\hline NFI & .97 & Perfect fit \\
\hline NNFI & .98 & Perfect fit \\
\hline CFI & .98 & Perfect fit \\
\hline GFI & .85 & Fairly good \\
\hline AGFI & .82 & Fairly good \\
\hline
\end{tabular}

Regarding the fit indices in Table 2, the expected and the observed difference between covariance matrixes was significant $\left(\chi^{2}(207): 595.34 ; \mathrm{p}<.05\right)$. $\mathrm{p}$ value was expected to be $>.05$. However, this value is significant depending on the sample size in most confirmatory factor analysis (Çokluk et.al., 2012). $\chi^{2} /$ sd value was calculated as 2.88 and indicated a perfect fit (Kline, 2005; Sümer, 2000). 
Regarding the fit of the model, RMSEA value close to zero is considered to be the indication of fitting (Steiger, 2007). In the current study this value was calculated as .077 and it is considered to be the indication of good fit (Hooper, Coughlan \& Mullen, 2008; Sümer, 2000). The value of the SRMR as .043 indicates a perfect fit (Brown, 2006). NFI value was .97, NNFI value was .98 and these values indicate a perfect fit (Hu \& Bentler, 1999; Sümer, 2000). CFI value, another criterion was calculated as .98 and according to several studies it is the indication of a perfect fit (Hu \& Bentler, 1999; Sümer, 2000; Thompson, 2004). GFI value was .85 and AGFI value was calculated as .82. As AGFI and GFI values are close to .90 , these two values are considered to be close to a good fit (Schumacher \& Lomax, 1996; Kelloway, 1989; Sümer, 2000).

All the indicators revealed that the model had a good fit and the scale could be explained in one dimension in good level. In order to reinforce the fit of the model error covariances were added and M7-M16 and M20-M22 items were associated. Path diagram regarding the model was given in Figure 2.

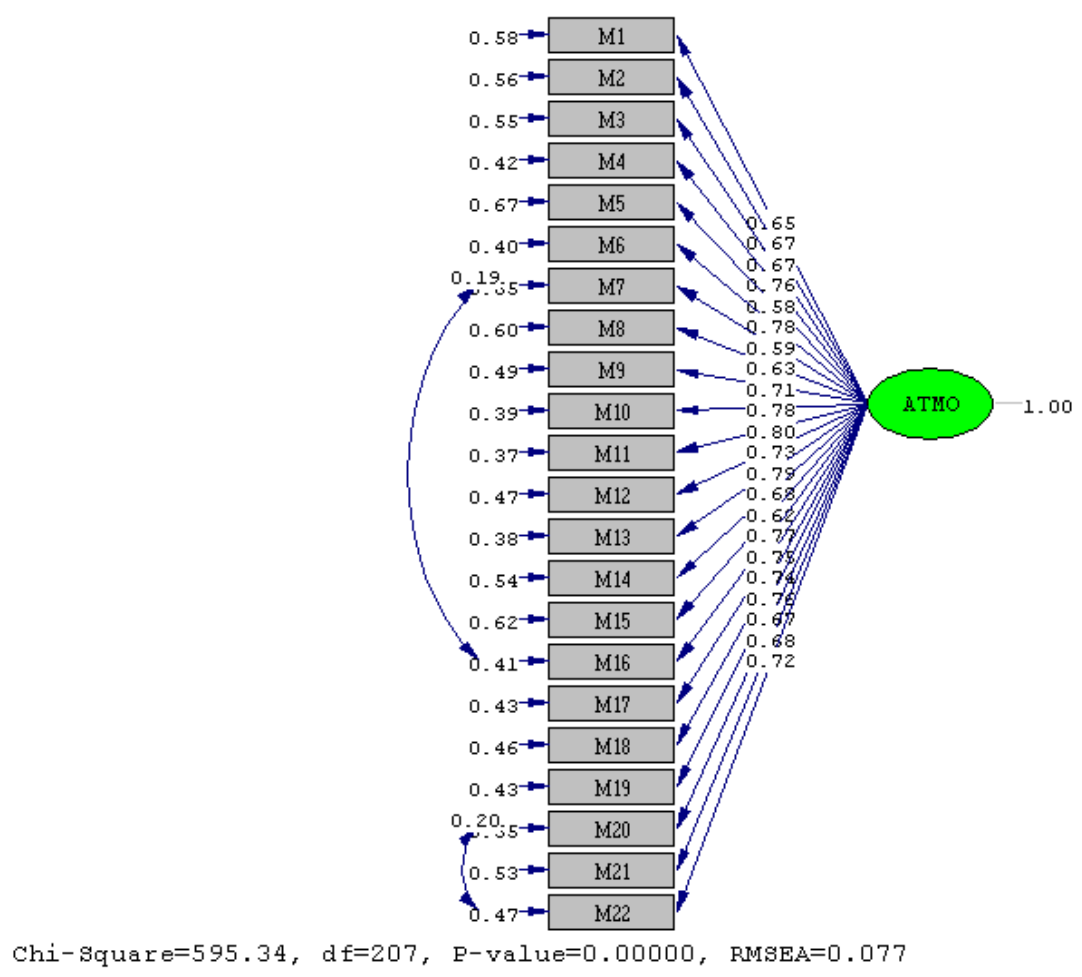

Figure2. Diagram regarding Structural Equation Modeling 
Correlation coefficient and error variance of each item were given in Figure 2. Correlation coefficients of the items ranged from .58 to .80 . Moreover, the values of the all items in scale were significant at the level of $\mathrm{p}<.05$.

\section{Results and Suggestions}

Smartphones are undoubtedly the most popular technological devices enabling the users with Internet, photography, e-mail, messaging, gaming, and etc. In recent years there has been a substantial rise in the sales of smartphones, and the average age of their owners and replacement cycle have decreased. In this context it is important to identify the motives and reasons why people replace their smartphones by spending high budgets. As Erkuş (2014) stated the measuring of a psychological variable stems from a necessity. In the current study a scale was developed in order to identify smartphone satisfaction of high school and university students between the ages of 15 and 22. Thus, an important data collection tool that will explore the replacement reasons, frequencies and smartphone satisfactions of adolescents while purchasing a new device has been presented in the literature.

27 high school and 31 university students, a total of 58 students were requested to write a composition on the satisfactions of their smartphones at the stage of item pool constitution. An item pool consisted of 46 items having positive and negative expressions was constituted as a result of the compositions and literature review. Pre-test application was conducted with a total of 70 volunteers, 38 high school and 32 university students after the expert review of the item pool.

For the construct validity of the draft scale, EFA was carried out through the data collected from 716 participants.Explained total variance rate of the single factor SSS consisted of 22 items was $39.360 \%$. Factor loads of the items ranged from .512 to .755 and Cronbach's Alfa $(\alpha)$ internal consistency of the scale was .932.

CFA was carried out through the data obtained from 316 participants in order to test the fitting of the model. All the indicators revealed that a single factor structure smartphone satisfaction scale at ideal levels by means of modification indices was valid and reliable, and it could be used in order to identify the smartphone satisfactions of adolescents in further studies. 
The technology that has changed and developed in time will give rise to production of new devices in the field of communication as in the other areas of our lives. Since the needs and the usage habits of an individual may change in time, it should be taken into consideration that this scale would no longerbe valid and reliable as the other scales in the long term.

The sample for the study consisted of adolescents between the ages of 15 and 22. Therefore, SSS was intended to be developed only for this age group. Several samples could be used for the other age groups and the construct validity and reliability of the scale for different profession groups are recommended to be reconstructed. 


\section{References}

Akbulut, Y. (2010). Sosyal bilimlerde SPSS uygulamaları. İstanbul: İdeal Kültür Yayıncılık.

Bal, E. (2013). Teknoloji çağında cep telefonu kullanım alışkanlıkları ve motivasyonlar:

Selçuk Üniversitesi öğrencileri üzerine bir inceleme. Yayımlanmamış Doktora Tezi, Sosyal Bilimler Enstitüsü, Selçuk Üniversitesi, Konya.

Böbrek, A. (2011). Sabit ve GSM telefon kullanıcılarının memnuniyet düzeylerini belirleyen faktörler üzerine bir araştırma. Tezsiz Yüksek Lisans Bitirme Projesi, Sosyal Bilimler Enstitüsü, Süleyman Demirel Üniversitesi, Isparta.

Brown, T. A. (2006). Confirmatoryfactoranalysisforappliedresearch. New York: GuilfordPress.

Büyüköztürk, Ş. (2009). Sosyal bilimler için veri analizi el kitabı(9. Baskı). Ankara: Pegem Akademi.

Büyüköztürk, Ş., Kılıç-Çakmak, E., Akgün, Ö. E., Karadeniz, S. \& Demirel, F. (2008). Bilimsel araştırma yöntemleri(2. Baskı). Ankara: Pegem A Yayıncılık.

Cohen, L.,Manion, L. \&Morrison, K. (2007). Researchmethods in education (6th ed).London: Routledge.

Comrey, A. L. \& Lee, H. B. (1992). A firstcourse in factoranalysis (2nd ed). Hillsdale, NJ: Erlbaum.

Çakır, F. \& Demir, N. (2014). Üniversite öğrencilerinin akıllı telefon satın alma tercihlerini belirlemeye yönelik bir araştırma. Dokuz Eylül Üniversitesi, I.I.B.F. Dergisi 1(29), 213-243.

Çakmak, T. \& Yalçın, H. (2013). Üniversite öğrencilerinin mobil veri kullanımı: Hacettepe Üniversitesi Bilgi ve Belge Yönetimi örneği. Hacettepe Üniversitesi, Türkiyat Araştırmaları Dergisi, 10(18), 47-61.

Çirkin, M. (2013). Piyasa gözetimi ve denetimi uygulamalarının tüketicilere etkisinin incelenmesi.Teknik Uzmanlık Tezi, Bilgi Teknolojileri ve İletişim Kurumu, Ankara.

Çokluk, Ö., Şekercioğlu, G. \& Büyüköztürk, Ş. (2012). Sosyal bilimler için çok değişkenli istatistik: SPSS ve LISREL uygulamalarl (2. Baskl). Ankara: Pegem Akademi.

Demirci, K., Orhan, H., Demirdaş, A., Akpınar, A. \& Sert, H. (2014). Akıllı telefon bağımlılığ ölçeğinin Türkçe formunun gençlerde geçerlilik ve güvenilirliği. Klinik Psikofarmakoloji Bülteni, 24(3), 226-234.

Erkuş, A. (2014). Psikolojide ölçme ve ölçek geliştirme I: Temel kavramlar ve işlemler(2. Baskl). Ankara: Pegem Akademi. 
Grigoroudis, E. \&Siskos Y. (2004). A survey of customersatisfactionbarometers:

Someresultsfromthetransportation-communicationssector. EuropeanJournal of OperationalResearch, 152(2), 334-353.

Güvenç, A. (2013). Kullanım dışı bırakılan GSM telefonlarının ıslahı ve imhası, dünya uygulamaları, ülkemize yönelik çözüm önerileri. Teknik Uzmanlık Tezi, Bilgi Teknolojileri ve İletişim Kurumu, İstanbul.

Hooper, D.,Coughlan, J. \&Mullen, M. (2008). Structuralequationmodeling: Guidelinesfordetermining model fit. The Electronic Journal of Business ResearchMethods, 6(1), 53-60.

Hu, L. T. \& Bentler, P. M. (1999). Cutoffcriteriafor fit indexes in covariancestructureanalysis: Conventionalcriteriaversusnewalternatives. StructuralEquationModeling, 6(1), 1-55.

Huck, S. W. (2012). Reading staticticsandresearch(6th. ed.). Boston: Pearson.

J. D. PowerandAssociates. (2014). U. S. Wireless Smartphone SatisfactionStudy - Volume 2. http://www.jdpower.com/sites/default/files/2014196\%20U\%20S\%20\%20Wireless\%2 0Smartphone-Traditional\%20Mobile\%20Phone\%20Satisfaction\%20StudiesV2_Final.pdf. RetrievedJuly 7, 2015.

Kalaycı, Ş. (2009). SPSS uygulamalı çok değişkenli istatistik teknikleri. Ankara: Asil Yayınevi.

Karaaslan, İ. A. \& Budak L. (2012). Üniversite öğrencilerinin cep telefonu özelliklerini kullanımlarının ve gündelik iletişimlerine etkisinin araştırılması. Journal of YasarUniversity, 26(9), 4548-4571.

Karasar, N. (1995). Bilimsel araştırma yöntemi: Kavramlar, ilkeler ve teknikler. Ankara: 3A Araştırma Eğitim Danışmanlık Ltd. Şti.

Kelloway, K. E. (1998). Using Liselforstructuralequationmodeling: A researcher's guide.London: Sage.

Kline, R. B. (2005). Principlesandpractices of structuralequationmodeling (2nd ed.). New York: Guilford.

Kwon, M., Lee, J-Y., Won, W-Y., Park, J-W., Min, J-A., Hahn, C. et.al. (2013). Development andvalidation of a smartphoneaddictionscale (SAS). PLoSOne, 8(2):e56936. doi: 10.1371/journal.pone.0056936.

Oliver, R. L. (1997). Satistaction; A behavioralperpective on theconsumer. Boston: McGrawHill. 
Sandıkçı, M. (2007). Müşteri memnuniyet ölçülmesi ve Sandıklı Hüdai Kaplıcasında bir alan araştırmas1. Afyon Kocatepe Üniversitesi, İI.B.F. Dergisi 2(9), 39-53.

Schumacher, R. E. \&Lomax, R. G. (1996). A beginner'sguide to structuralequationmodeling. New Jersey: Lawrence ErlbaumAssociatesPublishers.

Steiger, J. H. (2007). Understandingthelimitations of global fit assessment in structuralequationmodeling. PersonalityandIndividualdifferences, 42, 893-898.

Stevens, J. (1996). Appliedmultivariatestatisticsforthesocialsciences (3rd ed.).Mahwah, New Jersey: Lawrence Erlbaum.

Sümer, N. (2000). Yapısal eşitlik modelleri. Türk Psikoloji Yazıları, 3(6), 49-74.

Tabachnick, G. B. \&Fidell, L. S. (2001). Using multivariatestatistics(4th ed.). USA: Allyonand Bacon Press.

Taner, N. (2013). Kullanıcıların akıllı telefonları değerlendirmeleri: Kastamonu Şehir Merkezinde bir uygulama. Uluslararası İsletme ve Yönetim Dergisi, 1(2), 127-140.

Tavşancıl, E. (2006). Tutumların ölçülmesi ve SPSS ile veri analizi. Ankara: Nobel Yayın Dağıtım.

Thompson, B. (2004). Exploratoryandconfirmatoryfactoranalysis: Understandingconceptsandapplications. Washington, DC: AmericanPsychologicalAssociation.

Türkay, A. (2011). Satın alma davranışları açısından üniversite öğrencileri arasında marka bă̆ımlılı̆̆ının önemi: Batı Akdeniz üniversiteleri üzerinde bir uygulama. Yayımlanmamış Yüksek Lisans Tezi, Sosyal Bilimler Enstitüsü, Süleyman Demirel Üniversitesi, Isparta.

Türkiye İstatistik Kurumu [TÜİK] (2013). 06-15 yaş grubu çocuklarda bilişim teknolojileri kullanımı ve medya.http://www.tuik.gov.tr/PreHaberBultenleri.do?id=15866. RetrievedJune 22, 2015.

Türkiye İstatistik Kurumu [TÜİK] (2014). Hanehalkı bilişim teknolojileri kullanım araştırmast, 2004-2014.http://www.tuik.gov.tr/PreIstatistikTablo.do?istab_id=45. RetrievedJune 25, 2015.

Türkyılmaz, A. \& Özkan, C. (2005). Ulusal müşteri memnuniyet indeksleri. KALDER Forum, 16, 73-

77.http://www.fatih.edu.tr/ aturkyilmaz/documents/UMMI_KALDER.pdf. RetrievedJuly 5, 2015. 
Uzgören, E.,Şengür, M. \& Yiğit, Ü. (2013). Üniversite öğrencilerinin cep telefonu talebinde israfa yönelik davranışlarının analizi: Dumlupınar Üniversitesi öğrencilerine yönelik bir uygulama. Süleyman Demirel Üniversitesi, İ.̇.B.F. Dergisi, 1(18), 29-44.

WeAreSocial. (2015). Digital, Social\& Mobile in APAC

2015.http://wearesocial.net/blog/2015/03/digital-social-mobile-apac-2015.

RetrievedJuly 5, 2015. 


\section{APPENDIX A - Smartphone Satisfaction Scale (SSS)}

\section{(Translated Form for Readers)}

Dear students,

The following data collection tool was developed in order to determine smartphone satisfaction of yours. The obtained data will only be used for scientific purposes and there will be no individual assessment. Therefore, you do not need to write your names. The scale consisted of 22 items. Response time for the whole items in the scale is about 5 minutes. Please, read all the items carefully and mark the best choice for you.

Thanks for your participation.

\begin{tabular}{|c|c|c|c|c|c|c|}
\hline No & Concerning my smartphone; & $\begin{array}{ll}20 \\
0 \\
0\end{array}$ & 苞 & $\begin{array}{l}\bar{T} \\
\bar{E} \\
\bar{z}\end{array}$ & 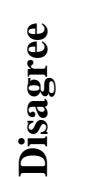 & 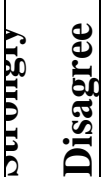 \\
\hline & & $(5)$ & (4) & (3) & $(2)$ & $(1)$ \\
\hline 1 & Quality of the images taken by the rear camera is high. & & & & & \\
\hline 2 & Call features (contacts, call history etc.) are good. & & & & & \\
\hline 3 & Screen size meets my needs. & & & & & \\
\hline 4 & Has an aesthetic appearance. & & & & & \\
\hline 5 & Sound quality of the speaker is ideal. & & & & & \\
\hline 6 & I like to use my phone. & & & & & \\
\hline 7 & I prefer the same brand if I replace my phone. & & & & & \\
\hline 8 & Allows me type easily. & & & & & \\
\hline 9 & Quality of the images taken by the front camera is high. & & & & & \\
\hline 10 & Processing speed is good. & & & & & \\
\hline 11 & Display quality of the screen is high. & & & & & \\
\hline 12 & Has ideal dimensions(height, width, depth) & & & & & \\
\hline 13 & Video shooting meets my needs. & & & & & \\
\hline 14 & Sound quality of the caller is ideal. & & & & & \\
\hline 15 & Has a good price in comparison to performance. & & & & & \\
\hline 16 & I recommend my phone to the others. & & & & & \\
\hline 17 & It reflects my style. & & & & & \\
\hline 18 & Sensitivity of touch screen is high. & & & & & \\
\hline
\end{tabular}




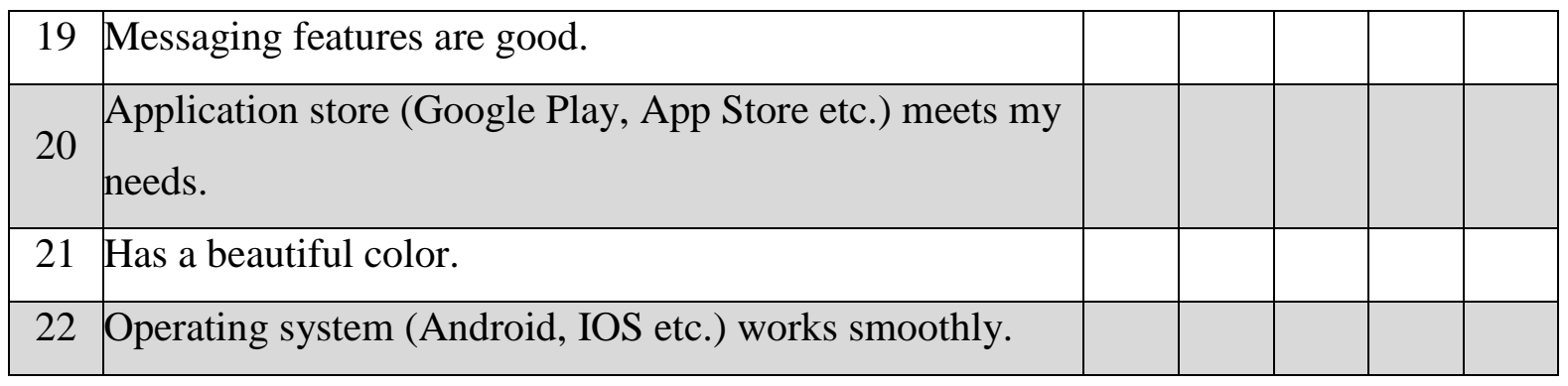

\section{APPENDIX B -Smartphone Satisfaction Scale (SSS) (Original Turkish Form)}

Sevgili Öğrenciler,

$\mathrm{Bu}$ veri toplama arac1, sizlerin ak1llı telefon memnuniyetlerini belirlemek amaciyla hazırlanmıştır. Elde edilen veriler yalnızca bilimsel çalışmalar için kullanılacak, bireysel değerlendirme yapılmayacaktır. $\mathrm{Bu}$ nedenle isminizi yazmanıza gerek yoktur. Ölçekte 22 madde yer almaktadır ve yanıtlama süresi yaklaşık 5 dakikadır. Lütfen maddeleri dikkatle okuyarak size en uygun olan seçeneği (X) ile işaretleyiniz.

Katılımınız için teşekkür ederiz.

\begin{tabular}{|c|c|c|c|c|c|c|}
\hline No & Akıllı telefonum ile ilgili olarak; & 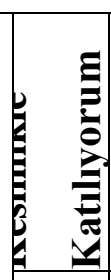 & 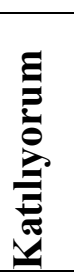 & 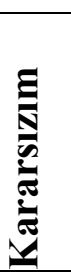 & 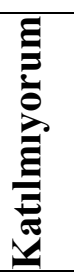 & 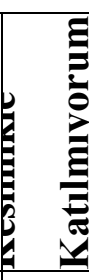 \\
\hline & & $(5)$ & (4) & (3) & (2) & (1) \\
\hline 1 & Arka kamera ile çektiğim fotoğrafların kalitesi yüksektir. & & & & & \\
\hline 2 & Arama özellikleri (rehber, arama geçmişi vb.) iyidir. & & & & & \\
\hline 3 & Ekran büyüklüğü ihtiyaçlarımı karşılamaktadır. & & & & & \\
\hline 4 & Görünüşü estetiktir. & & & & & \\
\hline 5 & Hoparlör sesi idealdir. & & & & & \\
\hline 6 & Telefonumu severek kullanıyorum. & & & & & \\
\hline 7 & Yine telefon alsam aynı markayı tercih ederim. & & & & & \\
\hline 8 & Kolaylıkla yazı yazılabilmektedir. & & & & & \\
\hline 9 & Ön kamera ile çektiğim fotoğrafların kalitesi yüksektir. & & & & & \\
\hline 10 & İşlem hızı iyidir. & & & & & \\
\hline
\end{tabular}




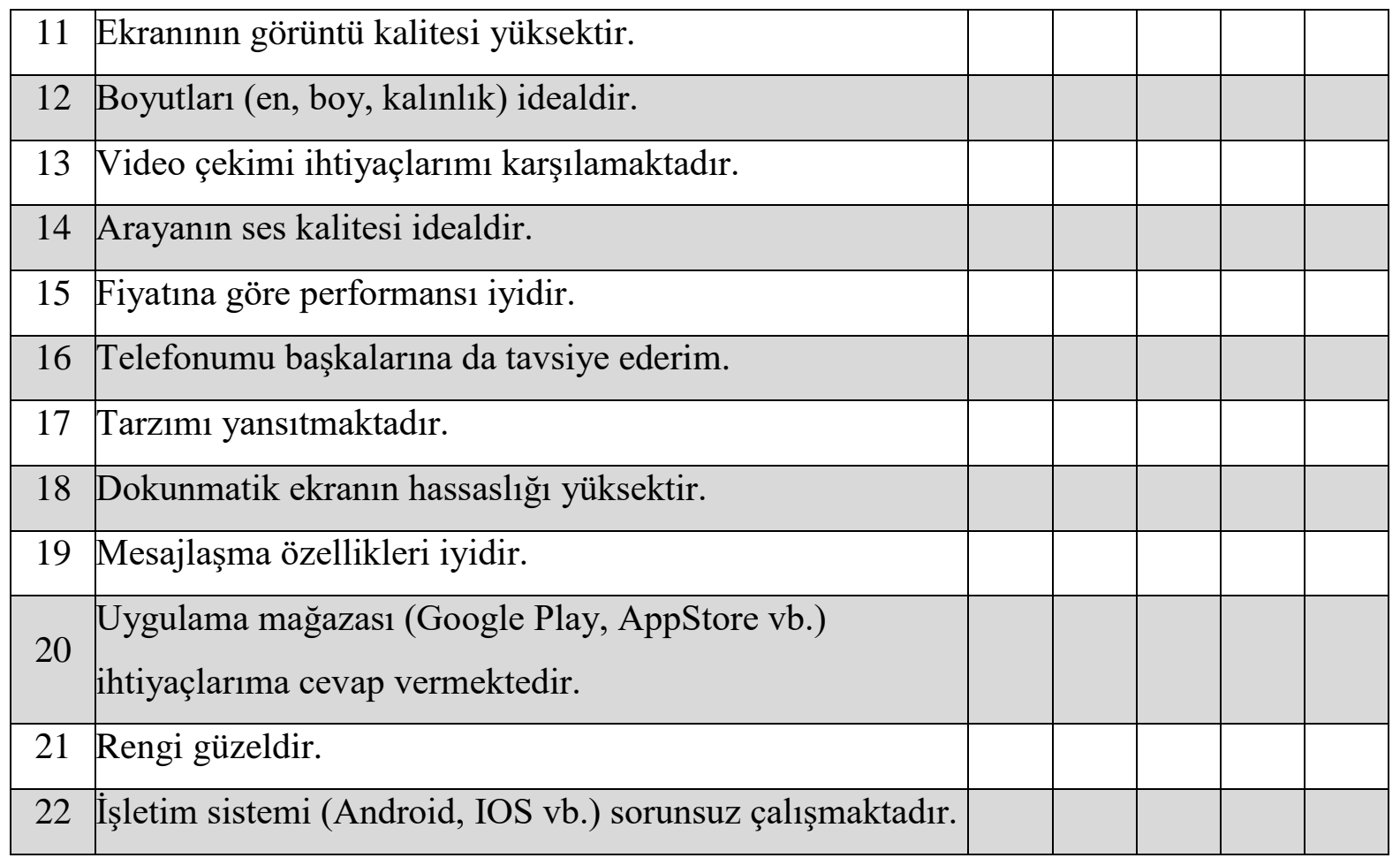

